\title{
College Athletes' Rights in the Age of the Super Conference: The Case of the All Players United Campaign
}

\author{
Ellen Staurowsky \\ Drexel University
}

\begin{abstract}
Among the most central ethical obligations that higher education in the United States owes to students is the protection of their right to freely disagree, form judgments on their own, and evaluate evidence (AAC\&U Board of Directors, 2006). This commentary argues that the ethical obligation to ensure that the academic freedom that should be available to all students is not met when it comes to the treatment of college athletes, most particularly those college athletes participating in the big-time, revenue-generating sports of football and men's basketball. Using the case example of the All Players United (APU) Campaign, a protest staged by less than two dozen college football players in the fall of 2013, issues associated with athletes right to freedom of speech and freedom of association are examined. The All Players United (APU) campaign is first described followed by an exploration of the group think evidenced in the reaction by college sport officials and football coaches to the APU. To provide context, the APU action is considered within a broader historical overview of college athlete protests and attempts to affect change in the areas of compensation, health and well-being, and educational access. Using a conceptual frame that recognizes that college athletes are recognized as neither workers nor students, difficulties associated with the location of college athletes' rights are explored. This commentary concludes with final thoughts regarding the implications of limiting avenues for athlete self-advocacy within higher education in light of efforts by the Northwestern football team to be recognized as employees with the right to unionize and collectively bargain.
\end{abstract}

Keywords: college athletes' rights, All Players United, NCAA, academic freedom, CAPA

Among the most central ethical obligations that higher education in the United States owes to students is the protection of their right to freely ". . . engage differences of opinion, evaluate evidence, and form their own grounded judgments about the relative value of competing perspectives" (AAC\&U Board of Directors,

Staurowsky is with the Department of Sport Management \& Media, Drexel University, Philadelphia, PA. Address author correspondence to Ellen Staurowsky at ejs95@drexel.edu. 
2006, p. 2). An argument is made that that ethical obligation is not met when it comes to the treatment of college athletes, most particularly those college athletes participating in the big-time, revenue-generating sports of football and men's basketball. Using the case example of the All Players United (APU) Campaign, a protest staged by less than two dozen college football players in the fall of 2013 , issues associated with athletes right to freedom of speech and freedom of association are examined.

The focus of this commentary is on the rights of college athletes in the bigtime sports of football and men's basketball. The intention here is not to ignore the concerns of other athletes across National Collegiate Athletic Association (NCAA) divisions. College football and men's basketball players serve as the labor upon which the financial model of the college sport industry is based. NCAA rule creation and adaptation is often motivated by the necessity of regulating conduct in the business of college sport. As a consequence, understanding how rights are accorded and denied to college football and men's basketball players offers a window into the ways in which the college sport industry works and the source of the controversies that often arise out of the practices that it adopts. The APU Campaign serves to illuminate the ethical tensions that emerge out of the competing interests of media and corporate entities invested in the spectacle of college football, higher education and its attendant constituencies, and the athletes who serve as the centerpiece of the college sport economic engine.

Information regarding the protest was obtained largely through media accounts as found through two online search engines-Google and LexisNexis-from the time of the first public sighting of the APU initials on a players wrist on Saturday, September 21, 2013 and in the four weeks following. Additional materials were obtained from the APU's sponsoring organization, the National College Players Association (NCPA) as well as two brief discussions with NCPA president, Ramogi Huma. Included here is also a discussion regarding the postscript to the APU, the action on the part of Northwestern football players to seek recognition as employees under the National Labor Relations Act (NLRA) and their right to collectively bargain as members of the College Athletes' Players Association (CAPA; Munson, 2014; Ohr, 2014; Vint, 2014).

A description of the All Players United (APU) campaign is followed by documentation of the group think that pervades college football as evidenced in the reaction of college sport officials and football coaches to the players' action. To provide context, the APU as a player-centered protest movement is situated within a brief historical overview of college athlete protests and attempts to affect change in the areas of compensation, health and well-being, and educational access. Using a conceptual frame that recognizes that college athletes were recognized as neither workers nor students until March of 2014 when the National Labor Relations Board (NLRB) in Chicago determined that Northwestern football players were employees (Munson, 2014), difficulties associated with the location of college athletes' rights are explored. This commentary concludes with final thoughts regarding the implications of limiting avenues for athlete self-advocacy within higher education, the leadership imperatives that have been ignored by college sport officials, and the open questions that remain for the future of college sport should the NLRB ruling that college football players are employees be upheld upon appeal. 


\section{Introduction: All Players United}

Sometimes the test of just how much control authorities have over individuals is found in the smallest of gestures. Such was the case on a Saturday afternoon in the fall of 2013 when less than two dozen college football players from the University of Georgia, Georgia Tech, and Northwestern wrote three letters-APU—on their wristbands. Symbolic of the term "All Players United", the APU Campaign was the creation of athletes who were members of the National College Players Association (NCPA; Associated Press, 2013a; Hruby, 2013c;). Searching for a way to lend support to fellow college football players who had signed on as plaintiffs to two different lawsuits challenging the NCAA for its failure to share revenues generated from the use of their names and likenesses in the generation of millions of dollars in annual revenue from television deals and other promotional activities and the NCAA's failure to protect athletes health by withholding information regarding concussions, APU signified an act of solidarity and protest for those who wore it. Players' identification with the APU also reflected their support for college sport reforms advocated by the NCPA that would provide for guaranteed scholarship renewals for permanently injured players and ensure protections for athletes harmed by NCAA rules (Associated Press, 2013b; National College Players Association, 2013).

Visually, the letters were barely discernible to anyone other than the players themselves and some of their teammates. In a sea of football players decked out in jerseys, shoulder pads and helmets who played that day, all branded with school and corporate logos, the few who stood up for themselves and a cause greater than themselves were difficult to identify. ${ }^{1}$ Photos attest to the fact that a sharp-eyed photographer with a zoom lens would be needed to even detect that the letters APU were handwritten on the players' gear. Many teammates of the players who wore the wristbands were not aware of the protest or what it was about. One coach indicated that he was so unaware that players on his team had opted to write APU on their wrists that he learned about it the way other people did, by seeing a news item streaming across the bottom of their television screen on a ticker (Emerson, 2013).

This protest was notable not only because it happened but because of its quiet simplicity. Amid the sounds of brass bands playing, shoulder pads hitting, whistles blowing, fans cheering, and commentators holding forth, the gesture amounted to barely a whisper. The reactions it provoked, however, reveal the degree to which college athletes' lives are controlled by college authorities and the level of deference college athletes are expected to give to those authorities. The reactions also demonstrate how hollow claims repeatedly made by college sport officials that the routine business practices associated with the college sport industry advance the interests of higher education often are.

At the local level, there was a contrast in the way head football coaches of major programs responded to the players who elected to make it known publicly that they supported the APU Campaign. Mark Richt, head coach at the University of Georgia, said,

We have the freedom of speech in this country ... but the question is what's the appropriate way of doing it. Based on what I read about, their concerns seemed pretty legitimate (Emerson, 2013, para. 10). 
Coach Richt would be one of the only people interviewed to acknowledge that that the players' action was a matter of freedom of speech. There was little if any public acknowledgment that the action also involved the right of athletes to freely associate with organizations that represented their interests.

Northwestern head coach, Pat Fitzgerald, was not as receptive to the position taken by quarterback and team leader, Kain Colter. Describing Colter's decision to make a statement by wearing the APU, Fitzgerald described it as a "teachable moment" that "was a great one for him and our ballclub" (Forde, 2013). He went on to say, "What we try to do here is keep things in a team context. When you decide to do something like that, I think it's a teachable and coachable moment" (Greenstein, 2013, para. 3). Reading between the lines, Fitzgerald's message was one that was discouraging of independent action, sincere conviction, and individual conscience.

Georgia Tech's coach, Paul Johnson, expressed similar sentiments (Forde, 2013). Reacting to the behavior of several Tech players who participated in the protest, he said, "Our team, we had a talk about, 'Hey, if it's going to be a team thing, we need to talk about it as a team. We need to take a team vote if everybody is in agreement or agrees, then OK, we can talk about what we can do" (Associated Press, September 23, 2013, para. 10).

Other coaches weighing in on the prospect of members of their teams speaking up only on the condition that the entire team speak up inspired a similar group think argument. University of Maryland coach Randy Edsall commented,

... again if our players had anything in regards to that, they'd come in and sit down and talk about it. If players are going to be involved in, really everybody should be involved. If everybody supports it, then fine. If it's a few individuals, I don't think that's, in my opinion, that's the team concept. Either everybody's in or you don't support that. Again, it's great players have that ability to express their opinions for what they might believe in (Prewitt, 2013, para. 5).

Kevin Wilson, the head football coach at Indiana University, was also in favor of requiring players to seek permission from the coaching staff and entire team. About players deciding to participate in the APU Campaign as individuals, he said, "We're going to look as a team and as a family. It we want to do something, we're going to do it collectively as a group, not as an individual" (Woods, 2013, para. 3). He went on to point out that "our tape [meaning athletic tape] is not a billboard", seemingly blind to the reality that while Indiana's tape may not be a billboard, the players certainly are as evidenced in the adidas logo situated just above "Hoosiers" in the center of their jerseys representing an agreement between the company and the program that would not have been subjected to a mandatory $100 \%$ vote by players (Woods, 2013). ${ }^{2}$

Coaches were not the only ones who offered perspectives that the players were out of line. Iowa State athletic director, Jamie Pollard, took to Twitter with several statements, starting with "Time for silent majority of student-athletes to take a stand, 'pay for play' is a fallacy by those that do not value education". He went on to write, "Yet to hear one realistic plan how to pay players without eliminating all other sports Value of Education versus Arena FB or D League" (Eifling, 2013, para. 3). ${ }^{3}$

Advocating the idea of retaliation against the players for expressing their views, broadcaster and former head men's basketball coach at Bowling Green 
and Indiana University, Dan Dakich, opined on Twitter that "It would be great if Georgia GaTech/Nwestern pulled the schollys of those that protested w the 'APU' sign/handed them student loans info" (Eifling, 2013, para. 4). Among the dozens of people who retweeted the message was NCAA vice president for Division III, Dan Dutcher, who wrote, "it would be great' if students who support \#APU had scholarships yanked" (Volk, 2013, para. 8).

The face for the protest soon became Northwestern's Kain Colter. When asked about his relationship with Coach Fitzgerald following the protest, he said,

I'm sure that he felt a little blind-sided by it. But in my perspective, it's tough to ask permission to be able to do something just because there's a chance it could get shot down. The whole APU thing, it goes against having to ask permission to voice our opinions (Gruen, 2013, para. 6).

Colter went on to say:

People shouldn't take it as an individual message. It's a sign of unity and not individuality. It's a sign of players coming together all over the nation. Not just football players - basketball players, tennis players - to be able to have our opinions heard. Even President Obama has said he's worried about college football players because they don't have a union and they don't have anything to fall back on if [injuries happen] (Gruen, 2013, para. 12).

The messages sent to Colter and his colleagues around the country designed to silence further public dissent must have seemed especially peculiar to him, a young man who would have watched as a third of students at Boulder (Co.) High School walked out of class in protest over the firing of his father, Spence Colter, as head football coach there in 2008. Colter, then a high school sophomore, was in the crowd that day as students rallied in support of his father (Miller, 2008).

On the surface, the NCAA appeared supportive of the athletes in their right to express their concerns. Within hours of the protest being launched, NCAA director of public and media, Stacey Osborn, said in a statement:

As a higher education association, the NCAA supports open and civil debate regarding all aspects of college athletics. Student-athletes across all 23 sports provide an important voice in discussions as NCAA members offer academic and athletic opportunities to help the more than 450,000 student-athletes achieve their full potential (Clifton, 2013, para. 6). ${ }^{4}$

The NCAA's statement not withstanding and apart from one NCAA official who was unbothered by calls for the athletes to be punished with the loss of scholarships, if players contemplating whether they wished to don the APU and join the campaign were weighing in the balance how college sport authorities would respond, the statement made by NCAA Division I athletic directors within five days would leave little doubt. A coalition of groups including the National Association of Collegiate Directors of Athletics (NACDA), the IA Athletic Directors' Association, the Football Subdivision Athletics Directors Association and the Division I-AAA Athletics Directors Association formed a few days later. Under the banner of 351 Division I Programs-One Voice, they announced that "As stewards of the enterprise, we are committed to providing meaningful, realistic and impactful 
leadership in defining a bright future for intercollegiate athletics" (Schott, 2013, para. 7). The Coalition was motivated to form out of concern over public dialogue that did not, in their view, ". . . accurately reflect the true value of intercollegiate athletics to student-athletes" (Schott, 2013, para. 9). ${ }^{5}$

As the main theme of the statement, the athletic directors offered outright opposition to a concept they were calling "pay for play", presumably in response to the NCPA's appeal that revenues generated by players be shared with them. In the 351 Division I Programs-One Voice (Schott, 2013, n.p.) statement, it read in part "Pay-for-play is not part of the amateur setting. There is no place for that." Morgan Burke, athletics director at Purdue and a designated spokesperson for the coalition, responded to a question regarding pay-for-play by saying "I don't believe you have ever seen any of us talk about something called "pay-for-play"” ("An interview with . ..," September 27, 2013, n.p.). He went on to say later in the interview, "There is no pay-for-play, at least not in my vocabulary" ("An interview with ... ", September 27, 2013, n.p.). Interestingly, the NCPA and the players joining the APU had not mentioned the expression "pay for play".

The careful attention to language and crafting of it belies the fact that the definition of amateurism within the NCAA manual does not expressly bar pay, simply pay that "... is not permitted by the governing legislation of the Association" (p. 58). In practical terms this means that pay is very much a part of the NCAA vocabulary. It is not opposed to pay, merely forms of pay that it cannot control (Staurowsky, 2004).

While there is an appearance that players' perspectives are valued in this process, the reaction of the athletic directors provides insight into just how little room there is for athletes to contest the way they are treated. While the athletic directors mobilized no less than four associations with corporate funding behind them and a long history of organizational support, the players themselves, dispersed across campuses and teams, have no such ready-made coalition building opportunity. At the time of the protest, the NCPA was the only player-centered organization with modest funding and a staff consisting of one full-time president, part-time clerical assistance, and reliance on volunteer assistance. ${ }^{6}$

Within a week, activity around the APU had all but disappeared from the national news. Football players at the University of North Carolina-Chapel Hill, offensive guard Landon Turner and wide receiver T. J. Thorpe, silently added the APU to their gear and other players may have done so well outside of the spotlight of media attention for a game on October 5, 2013 (Uthman, 2013). Two weeks later, their decision to participate in the protest was noted in USA Today (Uthman, 2013).

As NCAA Division I athletic directors staked out a part of the public dialogue highlighting the necessity to emphasize the value of education for college athletes, examining the reaction to the players who supported the APU is significant because it raises questions about what rights college athletes have and how much latitude they have to exercise those rights. When college athletes agree to an athletic scholarship and put on a uniform, are they precluded from speaking out about perceived injustice? Do coaches have the authority to limit a college athlete's ability to engage in a protest regarding health and safety issues, the manner in which they are treated, and the control exerted over their lives by athletic officials?

Asked to offer his perspective on the players who participated in the APU Campaign, former Green Bay Packer executive and ESPN football analyst, Andrew 
Brandt, commented, "The prism I look at things is always with the NFL and they would have obviously been using their uniform police. There'd be fines today for the APU things" (Ley, 2013). He went on to ponder if the players' actions might be an indicator that they were on the verge of organizing and that a collective bargaining agreement was in the offing (Ley, 2013).

Prophetic as that observation was, given that Northwestern football players sought to unionize in January of 2014 (Ohr, 2014; Munson, 2014), the case of the APU Campaign and college player involvement in it illustrates the unique nature of the relationship between scholarship athletes, their institutions, and the source of their rights. Restraints on individual NFL player conduct are negotiated under a collective bargaining agreement (CBA). NFL players may experience limits on their behavior so as to ensure that the profitability of their employers is not adversely affected by their individual actions. Whatever limitations that exist are negotiated as opposed to being unilaterally imposed and the interests of the players are represented by officials from the National Football League Players Association (NFLPA). In contrast, NCAA rules have been designed to preclude athletes from being recognized as workers and expressly prohibit athletes from having agents or other representatives to negotiate on their behalf. If the athletes who participated in the APU protest are not workers and do not have the rights of employees, then where is the source of their rights? It was that open question that logically led to the step that the Northwestern football players took to sign union cards so as to clarify the source of their rights as employees a few months after the APU protest through the College Athletes' Players Association (CAPA). The collision between the group think in operation within college football culture and academic freedom provides insight as to why the Northwestern football players pursued the course that they did.

\section{College Football Group Think v. Academic Freedom}

Before the March 2014 NLRB ruling that Northwestern football players were employees, the presumed student status of athletes located some of their rights in college and university statements regarding academic freedom and codes of conduct. In 1967, the American Association of University Professors (AAUP), along with several other higher education associations, issued the Joint Statement on Rights and Freedoms of Students. ${ }^{7}$ In the preamble, it states

Academic institutions exist for the transmission of knowledge, the pursuit of truth, the development of students, and the general well-being of society. Free inquiry and free expression are indispensable to the attainment of these goals. As members of the academic community, students should be encouraged to develop the capacity for critical judgment and to engage in a sustained and independent search for truth (p. 1).

At the University of Georgia, where Kolton Houston and fellow Bulldog linemen Chris Burnette, Kenarious Gates, John Theus and David Andrews wore the APU, the American Council on Education's (2005) Statement on Academic Rights and Responsibilities serves as a foundational document to establish student rights. Identifying intellectual pluralism and academic freedom as central principles of 
American higher education, it asserts "Because colleges and universities have great discretion and autonomy over academic affairs, they have a particular obligation to ensure that academic freedom is protected for all members of the campus community ..." (American Council on Education, 2005, para. 2).

The philosophical foundation for the University of Georgia's Code of Conduct further provides support for the rights of athletes as university citizens. Captured in a statement known as The Pillars of the Arch, three principles form the basis believed to be "necessary for us to be strong and complete citizens". Those pillars, or principles, include wisdom that "challenges us to apply lessons received inside and outside the classroom to our everyday lives"; justice that "leads us to be fair in our dealings, accountable for our actions, responsible for others, and empathetic for others"; and moderation that "compels us to act with civility, bolstering our faith in others and the faith others have in us" (Student rights . .., n.d.).

At Northwestern, its policy provides that "Students are free to form, join, and participate in any group for intellectual, religious, social, economic, political, or cultural purposes" and that "students are free to assemble, to demonstrate, to communicate, and to protest ... further recognizing the right of all faculty and students to pursue their legitimate goals without interference" (Northwestern policy ..., n.d.).

Nowhere in the statements above does it say that before athletes pursue the truth, engage in free inquiry and free expression, critically assess the world around them, and embark on a quest to find the truth that they first have to tell their coach and then act only after their entire team agrees. If the athletes who wore the APU were truly valued members of the academic community, the testimony of these athletes to what they perceive to be flaws and abuses in the system that jeopardized their health and well-being would have been applauded rather than subjected to attempts to suppress their behavior and repress their views.

The fact that college and university administrators-provosts and presidents-did not use the occasion to clarify the rights of students on their campuses is equally revealing. There were no public comments challenging the stated position of coaches to deny athletes the right to speak up if they were not speaking as part of their team. For all of the rhetoric around college athletes being an integral part of the student body and subject to the same rights and privileges, the beating heart of the academy - the ability of individuals to engage in open dialogue and freely engage in discussion-did not warrant a unified defense from either the academic or athletic community. In the midst of athletic directors invoking an amateur ideal as essential to the college sport experience, decrying the prospect of paying athletes, and pledging to offer a "quality education", the most fundamental principle at the core of higher education in America was being publicly violated by coaches without repercussion and with evidence that college sport officials agreed with them.

As Forde (2013) observed,

It is unlikely that a team would be in unanimous support of an APU statement. Opinions vary widely on the controversial issue of paying players, and many scholarship athletes undoubtedly would prefer the safe haven of saying or doing nothing. Which is why using unanimity as the veto card in this situation is a perfect dodge for coaches (para. 16). 
That safe haven could only exist if players were afforded the right to either agree or disagree. Thus, the coaches' position to insist on $100 \%$ agreement among players amounts to censorship of all positions (those in favor, those opposed, those unready to make a decision) and possible coercion (either we all do this or none of us do this). For a coach working at a state run school, athletes may well have a Constitutional right to free speech that cannot under the 14th Amendment incorporation of the Bill of Rights be infringed by a state institution. Two-thirds of NCAA Division I institutions are state institutions. As state actors, they are required to provide all civil rights to college athletes, whether federal or state (Johnson, 2010; Koller, 2012; Potter, 2007). Although freedom of speech has its limits, merely because a college football or men's basketball player puts on a uniform does not mean that he is required to abandon his right to think, to hold his own views, and express those views privately or publicly, especially when it comes to his own welfare. If $100 \%$ uniformity were expected, the only name on the uniform would be that of the school. As it stands in big-time programs, the name on the front of the uniform is that of the institution, while the name on the back is that of the individual. ${ }^{8}$

\section{Brief History of College Athlete Protests}

The collision over the status of athletes and their rights on college campuses has a long history. When college football players in the fall of 2013 marked APU on their wrists, they were engaging in a struggle and enacting a script that started at least 77 years before. One of the earliest athlete protests occurred at Howard University when football players refused to take the field against Virginia Union in 1936 demanding appropriate medical care for injured athletes, access to campus jobs, and nutritious food (McKenna, 2010). The following year, two football players would be dismissed from the Louisiana State University (LSU) team for attempting to organize a union (Fram \& Frampton, 2013). In 1937, the University of Pittsburgh football players, supported by their coach, Jock Sutherland, presented a list of three demands before they would agree to participate in the Rose Bowl that year. They asked for all members of the team to travel to the event rather than half of the squad, which had happened the previous year; that they be given adequate spending money; and that they be given a two-week vacation after the game was over. The crux of the dispute stemmed from the fact that the university had made $\$ 100,000$ off of their Rose Bowl win the previous year while each player on that team was given $\$ 7.50$ or less than $\$ 250$ as a team. In the process of acceding to their demands, the athletic director, Don Harrison, resigned and the Chancellor, John Gabbert Bowman, vowed to institute reform to bring players in line (Oriard, 2003).

Similar confrontations between college football players and their home institutions would take place across the country in the 1930s and 1940s, chronicled in the pages of the Daily Worker (Oriard, 2003). Sutherland would eventually be fired at Pittsburgh as Bowman sought to limit player compensation, issuing the players tuition bills that they were expected to pay after being told that their education would be paid for by the school. In 1940, Stanford players successfully embarked on their own quest to be paid $\$ 50$ for participating in the Rose Bowl. At the University of Arizona, players would seek $\$ 175$ each but were denied that consideration by their administration (Oriard, 2003). 
In 1945, Wake Forest football players who were reluctant to go play in the Gator Bowl at season's end were incentivized to play when boosters offered to pay each member of the team $\$ 100$. After thinking about the offer for a few days, players countered with a proposal that starters should be paid \$150. As Southall (2012) noted, "The players were not uncomfortable turning their backs on amateurism and getting paid; they simply felt starters should be paid more than non-starters" (p. 3).

In 1961, a showdown between college football players and a head coach would occur at the Liberty Bowl in Philadelphia, an apt setting given the revolutionaries there who signed the Declaration of Independence in 1776. The Liberty Bowl was a made-for-TV bowl game featuring Syracuse University and the University of Miami. Frustrated at the prospect of giving up their holiday season to play in a game that financially benefitted others but offered nothing to them, Syracuse players delivered an ultimatum to their head coach, Ben Schwartzwalder. Noticing that players in other bowl games had been awarded complementary wrist-watches, the Syracuse players demanded the same and threatened they would not go on the field unless their demand was met. The game was played and the players got their watches (Meggysey, 1970).

Later in the decade, Coach Schwartzwalder and the Syracuse football program would face more player unrest when racial tensions rose in the aftermath of a fight that occurred between a black student and white football player in 1969. By the following May, a group that became known as the Syracuse Eight boycotted spring practice in an attempt to bring attention to ongoing racial discrimination and insensitivity (Rhoden, 2006; Wiggins, 1988). The walk-out by black players at Syracuse was indicative of player protests occurring at many colleges and universities around the country between 1968 and 1972 as the Civil Rights Movement came to an end.

As Wiggins (1988) wrote, "Life on America's predominantly white university campuses. . . . was anything but tranquil" (p. 304). As part of black student revolt on college and university campuses during that time, “.... sociologist Harry Edwards estimated that in 1968 alone some thirty-seven black athletic revolts took place on predominantly white university campuses" (p. 305). In a three-part series entitled "The Desperate Coach" published in August of 1969, Sports Illustrated reporter John Underwood described the perceived assault on the authority of college coaches who were unaccustomed to being questioned by players about the behavior codes imposed on them. Capturing the tone and tenor of the time, Underwood (1969) wrote, "In the privacy of their offices, over breakfast in strange towns, wherever two or three coaches get together, they talk about The Problem" (para. 20). And "the problem" as coaches called it went beyond clashes between black players and white coaches. White players, as well, objected to the way that coaches treated teams generally.

Describing this time, Michael Oriard (2009), a leading cultural historian of college football, noted ". . . matters of team discipline to coaches were concerns of fairness or human rights to the players" (para. 5). Out of those confrontations, small victories were won for players with coaches conceding ground on personal grooming (hair length, facial hair, and attire), more black assistant coaches were hired, and overt racial insensitivities were addressed. For the players who boycotted, some were never permitted to return to their teams, others returned but never felt that they were welcome, and still others found it difficult to get jobs in athletics after being identified as troublemakers. Coaches, in turn, found a way to regain 
control over the athletes on their team. "In January of 1973, the NCAA quietly passed legislation replacing the four-year athletic scholarship with a one-year renewable grant" (Oriard, 2009, para. 8). With the passage of the one-year renewable, the NCAA effectively solidified coach power over athletes, severely limiting the opportunities athletes would have to advocate on their own behalf.

In the 1980s, two attempts were made to develop player advocacy groups. Former Duke men's basketball player, Dick DeVenzio, created the College Athletes Association in an effort to advocate for stipends and increased benefits for athletes. Believing that player boycotts would be the most effective way to get college sport officials to respond to player concerns, he attempted to persuade teams to engage in public demonstrations by delaying the start of games or refusing to play in games all together (Staff, 1986). Players inclined to support the idea of protesting, however, believed that the pushback from angry audiences and from their own teams would pose too big of a hurdle to overcome. The closest thing to a player action came in a highly publicized game between Oklahoma and Nebraska in 1986, when players elected to pause before the start of the game and pray (Kindred, 2011).

The Center for the Rights of Athletes in Education (CARE) was a project undertaken by former Notre Dame football player turned sociologist, Allen Sack. With funding from the U.S. Department of Education Fund for the Improvement of Post-Secondary Education (FIPSE) through an umbrella organization called Sports for the People, CARE sought to inform college athletes of their rights and offer crisis intervention teams to athletes who were dismissed from their programs, had their athletic scholarship removed, or were denied due process (Sack, 1982). According to Sack (2008), funding would eventually be pulled from the project for political reasons. In a response to several members of the U.S. Congress who wanted to know why funding had been withdrawn, Sven Groennings, the director of Fund for the Improvement of Post-Secondary Education (FIPSE) wrote,

... it was our feeling, after careful monitoring, that the activities CARE was undertaking with public educational dollars were primarily advocacy and not educational. Although we recognize CARE's excellent ability to raise public awareness of abuses in college athletics, we felt that their treatment of the issues was often one-sided and confrontational (as quoted in Sack, 2008, p. 95).

As the sun set on CARE in the 1980s, it appeared that a player boycott would happen in 1995. According to former University of Massachusetts forward Rigo Nunez, a player strike was planned to occur during critical postseason men's basketball games (Hruby, 2013b). Describing the reaction from officials and coaches when they learned of the scheme, "If we had Twitter, if we had Facebook, this would definitely have had an impact on the NCAA tournament. Player commitment to the boycott evaporated, however, amidst fear that those participating would be 'blackballed' and labeled 'troublemakers"” (Fram \& Frampton, 2012, p. 1073).

By the late 1990s, a new organization led by a former University of CaliforniaLos Angeles (UCLA) football player, Ramogi Huma, would come into existence. Known as the NCPA, its mission is to "provide the means for college athletes to voice their concerns and change NCAA rules" (NCPA, 2013, n.p.). The role of athlete advocate was one that Huma embraced while a player in the football program at UCLA. It was there that he started to think about how college athletes could play a role in influencing public dialogue on issues of the day (Kaufman, 2010). When 
his all-American teammate, Donnie Edwards, was suspended by the NCAA for accepting groceries after his scholarship money ran out at the end of the month, Huma became motivated to address the realities of what was happening in the lives of players that the NCAA and college sport officials were unwilling to address.

The NCPA has worked to effect change on behalf of Division I football and men's basketball players in areas of medical coverage, health and safety issues, and fair compensation. NCPA sponsored legislation has been passed in both California and Connecticut. Those laws include a requirement to disclose conditions under which an athlete may retain or lose an athletic scholarship and to pay for deductibles up to five years after an athlete has sustained an injury. Through the work of Huma and Staurowsky (2010, 2011a, 2011b, \& 2013), there is greater public awareness that NCAA limits on scholarship assistance mean that the popular notion that athletes attend college on a "full" or "free" ride is a fallacy.

While the APU Campaign was underway, another college football player boycott unfolded at Grambling State (Schroeder, 2013). As a program in upheaval due to instability in coaching and the challenges of low financial resources, resulting in players practicing and competing in unhealthy conditions and in deteriorating athletic facilities, players sat out two practices and a game against Jackson State in the hope of raising awareness regarding their plight (Schroeder, 2013).

While these moments of college athlete resistance have at times influenced the dialogue and provided fodder for media, little has changed in the status of college athletes in the revenue-producing sports. Characterized by Southall and Weiler (2013, n.p.) as "profit" athletes who are in the improbable position of working in a system that generates millions of dollars off of their labor while freely distributing that money to others (Fram \& Frampton, 2012; Staurowsky, 2004), college athletes in the revenue-producing sports of football and men's basketball have heretofore lived in a netherworld where their lack of recognition as employees denies them of rights under that status and where their rights as students are routinely abridged.

\section{College Athletes as Neither Workers nor Students}

This negated status of big-time college football and men's basketball players as neither workers nor students is achieved through the NCAA's principle of amateurism, and the athletic scholarship is used as a means of controlling an otherwise unnamed labor force. In his memoir entitled Unsportsmanlike Conduct, the first full-time executive director of the NCAA, Walter Byers (1997), wrote that "Amateurism is not a moral issue; it is an economic camouflage for monopoly practice" (p. 376), a concept designed to protect the business of college sport but not the athletes who generate the revenue on which the business is built.

Nearly three decades ago, tennis legend and civil rights advocate, Billie Jean King (1986), who challenged the tennis establishment to abandon its form of amateurism, wrote in Women's Sport \& Fitness magazine that the NCAA's concept of amateurism symbolized a power struggle between college sport officials and athletes. In an interview in September of 2013, King was asked what she thought of the current conversations regarding NCAA reform, saying, "I just think they need to change 'scholarship' to 'contract' because that's really what it is. I just think it's semantics a lot of the time and I just think we should be above-board" (Rosenberg, 2013). 
Tracing the semantics around the athletic scholarship offers evidence that college sport officials have not always been above-board with their intentions. As members of the NCAA debated whether they were going to adopt athletic scholarships ${ }^{9}$ in 1956, University of Michigan athletic director and famed football coach, Fritz Crisler, said:

We were foreswearing old amateur principles without admitting it. We're saying that these youngsters are amateurs and nobody should be permitted to professionalize them except the colleges. The colleges can pay them (Byers, 1995, p. 73).

The codification of the athletic scholarship, which was understood to be pay for play, would lead to all manner of obfuscations on the part of the NCAA in the years ahead. When confronted with former athletes who successfully argued for workers compensation benefits following injuries, the NCAA set about the task of mounting a public relations campaign to deflect attention away from the fact the athletes whose labor on the field provided for other people to have jobs and medical benefits were being denied those same considerations. Athletic scholarships were artfully referred to as "gifts" or "grants-in-aid". As scholarship athletes were being viewed by the courts as employees, the NCAA set out to weave a legal fiction in the form of the term "student-athlete" (Byers, 1995; McCormick \& McCormick, 2006, Sack \& Staurowsky, 1999; Staurowsky \& Sack, 2005). In an admission that would come from Walter Byers (1995) directly, he wrote:

We crafted the term 'student-athlete', and soon it was embedded in all NCAA rules and interpretations as a mandated substitute for such words as players and athletes. We told college publicists to speak of 'college teams', not football and basketball 'clubs', a word common to the pros (p. 69).

The propaganda machine behind the use of the term "student-athlete" has achieved its intended result by making it ubiquitous within the culture. Given its strategic purpose, the "student-athlete" term of art has also camouflaged a system that researchers and writers have alternately likened to a form of indentured servitude (Belzer \& Schwartz, 2012) or a plantation system (Branch, 2011; Byers, 1995; Hawkins, 2010). Described by Fram and Frampton (2012) as "a valuable consideration for services rendered," the athletic scholarship itself has been likened to that of company scrip (McCormick \& McCormick, 2006; Southall \& Weiler, 2013). Comparing athletic departments to modern company towns, the scholarship functions in much the same way that scrip did, where the "currency" was redeemable only within the very narrow confines of the town itself and within an economy established by the owners (McCormick \& McCormick, 2006; Southall \& Weiler, 2013).

\section{College Athlete Rights Fall Through the Cracks Between Worker and Student Statuses}

In the netherworld that has existed for college athletes between bona fide workers and students, their ability to access their rights becomes more difficult. As 
determined by the courts and institutional policy, college and university officials can regulate student speech and group association when it presents harm to those in class or on the campus, violates a state or federal law, or threatens damage to property and individuals (Walsh, 2011). Under that general understanding, those participating in the APU protest were well within their rights to wear the initials as they did. Still, the question of whether the rights of college athletes to speak out and to associate with groups of their own choosing are the same as the typical college student is not as evident as it may appear.

Other constitutional rights of college athletes have been abridged by NCAA rules. For example, the requirement that athletes participate in suspicionless drugtesting has resulted in athletes giving up their right to privacy to remain eligible (Walsh, 2011). First Amendment issues have arisen as college athletes have sought to engage with family, friends, and fans on social media (Gay, 2012; Hauer, 2012; Walsh, 2011). Overly restrictive social media policies adopted by some colleges and universities that resulted in violations of athlete privacy and censorship resulted in the passage of laws in California, Delaware, Michigan, New Jersey, and Utah (Shear, 2013).

The lives of college athletes are routinely regulated in ways that distinguish them from their colleagues in the general student population. From training rules to dietary habits to sleep times to dress codes, coaches and athletic department personnel concerned with the brand and the product have developed over the years a detailed set of guidelines by which athletes must live to earn and to keep their scholarships. Athlete self-expression in the form of tattoos and body art may be muted with requirements to cover those up when playing. Some programs, such as Alabama football, ban first year players from speaking to the press (Penrose, 2013).

Perhaps it is no wonder then that college athletes with the largest public platform (i.e., football and men's basketball players) and presumably the most leverage to assert their voice in raising issues that affect their lives are hesitant to do so. Such hesitancy offers compelling witness to the vulnerable position athletes occupy within colleges and universities. ${ }^{10}$ Although NCAA regulations put forward the idea that college athletes are like all other students, their status is defined by the conditions that need to be met to retain a college scholarship. With pressure to perform athletically to retain a scholarship, in an atmosphere where questioning the status quo is not welcome and with an expectation that players will not go public with their grievances for fear of damaging the program and their own prospects, there is considerable risk associated with player activism (McCann, 2013a; 2013b).

The APU Campaign offers insight into the ways in which NCAA and athletic department rules are brought to bear in controlling the lives of athletes. As a case in point, any commercial value that the athletes might have been able to use in generating funds to support the APU effort was essentially foreclosed by NCAA rules. If athletes involved in the campaign had sought to merchandize and sell clothing with APU on it they might well have been subject to NCAA prohibitions against athletes receiving remuneration for capitalizing off of their athletic ability. If another entity had funded merchandise and given it to those athletes to wear, they would have violated NCAA rules if they had accepted because they would have received a benefit that other students had not been given. They would not be able to go onto a website such as Kickstarter (a grassroots fundraising website) to seek public support for their position that would allow them to conduct sustained 
lobbying and media campaigns. Departmental social media policies might have deemed efforts to create and mobilize networks of support as distracting to the programs, warranting player sanctions. Operating under the conditions of a one-year scholarship, if athletes were determined to be too disruptive to a team or program, they could potentially be dismissed. Members of the media wishing to interview players who protested would most likely have had to go through athletic department media relations staff to gain access, and the players might well have been monitored by athletic department personnel when they were being interviewed. Given that football and men's basketball players report that they devote 42.45 and 39.2 hours to their sports and are engaged in 82 and 76.5 hours between their athletic and student commitments per week (NCAA, January 2011), their ability to organize or put up a significant challenge is severely limited. In turn, the limits coaches sought to impose on the athletes involved would not be tolerated if athletes were permitted to subject their coaches to the same standard. While players are not consulted when coaches leave programs to pursue other opportunities, transfer rules require athletes to get the permission of coaches before attempting to pursue opportunities elsewhere.

\section{The APU Post-Script: Northwestern Football Players as Employees}

The decision on the part of NLRB regional director, Peter Ohr (2014), to recognize Northwestern football players as employees represents a first step in the process of college football and men's basketball players in big-time programs to collectively bargain for health care, compensation, and other benefits while negotiating the terms and conditions under which they play.

The ruling itself is significant from the standpoint that an objective party considered the common law definition of employee, matched up the experience of college football players at Northwestern to that definition, and concluded that the primary relationship that existed between football players and the University was that of an employee/employer (Munson, 2014; Ohr, 2014). ${ }^{11} \mathrm{Ohr}$ (2014) cited work weeks that often exceeded 40-50 hours, the contractual nature of the relationship as outlined in the National Letter of Intent, the control coaches had over the lives of the athletes, and the fact that the athletic scholarship was legal tender for the job of being an athlete as evidence of the athletes' roles as employees. In effect, Ohr was not persuaded that the principle of amateurism, despite protestations from Northwestern, governed the lives of the athletes in the case.

Northwestern University has vowed to appeal (Munson, 2014). And NCAA Chief Legal Counsel, Donald Remy (2014), issued a statement acknowledging that improvements in the system did need to be made. He also suggested, however, that the players' efforts were misdirected given that "Over the past three years, our member colleges and universities have worked to re-evaluate the current rules." (n.p.) What these responses forebode is that college sport officials will continue to operate under an old playbook and will battle the very athletes who have waited decades for resolutions to issues that affect their lives during their playing days and after they move on with their lives, often suffering serious long-term health problems without benefit of insurance coverage well after their playing days are over. 


\section{Conclusion}

While college sport authorities sought to shut down the voices of dissent among the football players who participated in the APU Campaign, some members of the U.S. Congress did hear the message (Wolverton, 2013). Within weeks of the protest, Representative Tony Cardenas (D-CA) introduced The Collegiate Student Athlete Protection Act (CSAP Act; Staff, 2013) which addresses among other things the need for medical bills incurred as a result of injuries college athletes suffer in the course of their college careers to be paid by their schools, prevents schools from taking away athletic scholarships as a result of athlete injury or without cause, and calls for increased graduation rates. The CSAP Act was cosponsored by the Oversight and Government Reform Committee including senior ranking member Elijah Cummings (D-MD), Charlie Rangel (D-NY), Tim Ryan (D-OH), Jared Huffman (D-CA), and Betty McCullom (D-MN; Staff, 2013).

The fact that the U.S. Congress has taken an interest in the message of the APU, along with the public spotlight in which the protest occurred most likely ensures that the athletes who engaged in the protest will be somewhat protected as a result of speaking out. Still, in the quiet of postseason, players can be deftly moved out of a program with little notice, thus the fate of those who participated in the APU remains in question. The CSAP Act seeks due process protections for athletes who lose their athletic scholarships. And while NCAA rules already provide for athletes to receive at least one administrative hearing following scholarship reductions and losses, the one-year renewable arrangement stipulates that awards are not guaranteed.

Despite its veneer of homespun local tradition and community pride of place for college graduates and regional fans, the big-time college sport industry is no place for amateurs (Staurowsky, 2004). If the United States government is so concerned with promoting democracy around the world, perhaps the felt necessity to do so should be directed toward the nation's college athletic teams that resemble totalitarian regimes that strip athletes of fundamental rights as workers, as citizens, as students, and as human beings. ${ }^{12}$ Consider the unified message from coaches to the athletes who wore the APU that they not go outside the chain of command in expressing their concerns, that they not say or do anything that would reflect negatively on the business of college football, that their viewpoint could only be validated if $100 \%$ of the team and the coaching staff agreed with it, and that they speak publicly only on positions preapproved by the team. That message bears a remarkable resemblance to Benito Mussolini's statement regarding totalitarianism as "Everything with the state, nothing outside the state, nothing against the state" (as quoted in Enrie, 2010). Although it would be an over-exaggeration and distortion to liken college football programs to totalitarian states, nevertheless the logical framework is in operation, a framework that discourages democratic thinking and creates fertile ground for anti-intellectualism.

From the days of the "desperate coach" in the 1960s to the present, leaders within the college sport enterprise have sought to control athletes and limit their capacity to negotiate and challenge the rules that are imposed on them. ${ }^{13}$ This cultural mindset and antidemocratic leadership practice may well be the reason why college football players, both past and present, are coming forward in record numbers to assert a voice in their own fate. 
The APU Campaign did not occur in a vacuum, nor did the movement on the part of the Northwestern football players to seek protections under the NLRA. Both current and former college football and basketball players have filed lawsuit after lawsuit during the past 10 years in attempts to have their concerns heard regarding improper use of college athlete names and likeness (O'Bannon v. NCAA, 2009; Keller v. NCAA, 2009); unlawful limits on compensation as imposed by the NCAA's definition of an athletic scholarship (Jenkins v. NCAA, 2014; Weiner, 2012), failure to protect college athletes from harm and provide for them when they are injured (Arrington v. NCAA, 2011; Doughty v. NCAA, 2013), and denial of due process (Fitzgerald, 2009; Oliver v. NCAA, 2009). The college sport establishment's position thus far has been to fight every lawsuit with all of the financial wherewithal, media access, and political power it has at its disposal (Berkowitz, 2013).

In doing so, college sport officials fall prey to their own rhetorical creation, that being the "college kid" who is just playing for the love of the game. Northwestern's Kain Colter, Georgia's Kolton Houston, and the ever growing list of college football and men's basketball players organizing in their own interests to seek redress for past harms in terms of a system that has not protected players' health and has undervalued their contributions to a college sport industry conservatively worth $\$ 18$ billion, are not acting like children, but the young adults they are.

But how are those in college sport acting in contrast? Over and over again, signs point to the fact that there is a leadership crisis when it comes to the oversight of college sport. Writing about presidential leadership, Hoffman (2013) noted that college presidents operate in a unique environment where ambiguity and anarchy are structural conditions that create an unstable base of power from which they operate. This sets up a backdrop for college presidents to be operating from a position of weakness while big-time athletic programs, self-contained as they are with links to conferences, have their own competing bases of power. As a result, "Athletic directors and conference commissioners drive conference level decisionmaking with regard to lucrative BCS television contracts (Knight Commission on Intercollegiate Athletics, 2001) and conference realignment that feature football interests over other campus interests" (Hoffman, 2013, p. 12). Consider the Inside Higher Education poll that found only $13 \%$ of college presidents believed that their peers at colleges and universities that sponsored big-time college sport programs had control over those programs (Green, Jaschik, \& Lederman, 2012). It is in this space where high profile coaches with widespread booster support and compensation packages that often times situate them as the highest paid public employee in most states in the Union establish their own power bases, leveraging public sentiment to their advantage. The result of this imbalance of power is a system of decision- making that lacks transparency and checks and balances, leading to significant conflicts of interest. Thus, while the players struggle to have their issues heard, the decision makers within the college sport industry pass rules that reflect their own conflicts of interest.

As one example, while athletes are barred from having agents so as to protect them from people who would otherwise exploit them, the very people imposing that regulation (coaches, athletic directors, conference commissioners) have agents who assist them in negotiating contracts. As a result, while athlete access to advocacy is restricted, those responsible for the rules are profiting handsomely from the system that they regulate. While compensation for football coaches during the past 
15 years replete with ever expanding bonus categories, annuities, and amenities such as corporate jets has increased by $650 \%$, as a case in point, compensation in the form of a full athletic scholarship for football players on the field has remained stagnate, stuck in the 1950s (Hruby, 2013a; Staurowsky, 2011).

And as the leadership fails, and serves its own interests, the central concerns of the athletes go unattended. To allow for the obvious exploitation and abuse of young people whose lives, bodies, and futures are monopolized and monetized in service to feeding a public appetite for entertainment and a corporate appetite for profits reveals the degree to which higher education abdicates its moral center and ethical responsibilities to accommodate the college sport industry. ${ }^{14}$ It also reveals how shallow the claims are that college sport does not corrode the essence of what higher education in the American democracy is about. As the Association of American Colleges and Universities (AAC\&U) Board of Directors wrote in 2006, academic freedom is ". . . an essential precondition to fulfill the academy's mission ..." and "... to sustaining a society that is free, diverse, and democratic" (p. 2). Within the walls of academia, where college athletes should be both free to express their views and protected when they do so, they are the most vulnerable to routine violations of their rights as citizens, employees, students, and human beings. Historian Taylor Branch (2011) and Billy Hawkins (2010) remain among the few commentators on college sport who grasp that until such time as the rights of the players themselves are placed at the center of college sport reform and protections in place to uphold those rights little will change.

\section{Notes}

1. According to the FBS television schedule for Saturday, September 19, 2013, 112 teams competed that day. A conservative estimate of the number of players who were dressed and on the field that day is 9,520 , accounting solely for those on full scholarship. The figure is probably close to 12,000 . https://www.google.com/webhp?hl=en\&tab=mw\#hl=en\&q=FBS+schedule+Sa turday+September+21\%2C+2013

2. On Sunday, October 6, 2013, the Indiana University football site featured photos of the team. The description above is based on those photos found here: http://www.iuhoosiers.com/ sports/m-footbl/ind-m-footbl-body.html

3. This quote reflects how the focus of the APU protest by athletes over health care and the lack of control they have over rules was misrepresented as an attempt at "pay for play".

4. The NCAA is a sport governing body. Simply because its members are colleges and universities does not necessarily qualify it as a higher education association. The National Federation of State High School Associations, in contrast, is never referred to as a secondary education association. It describes itself as a "national leadership organization for high school sports" (NSFHA, 2013).

5. The statement under the banner 351 Division I Programs-One Voice was also available on the National Association of Collegiate Directors of Athletics (NACDA) website: http://www. nacda.com/sports/nacda/spec-rel/092513aaa.html

6. NACDA's website lists no less than 50 corporate sponsors including media entities (CBS Sports, Fox Sports, USA Today Sports), apparel companies (Under Armour), media technology companies (NewLion), athlete representation and marketing firms (IMG), beer company (MillerCoors), airline (United), and others: http://www.nacda.com/ According to the NCPA's Form 990 for 2010, the Association had less than a quarter of a million in assets from contributions. Reported 
expenses went primarily to compensation for the staff and lobbying efforts: https://bulk.resource. org/irs.gov/eo/2012_06_EO/02-0635571_990_201012.pdf

7. This statement would be reviewed again in September 1990, September 1991, and November 1992 (AAUP, 1992).

8. The juxtaposition of the different names on the front and the back of the jersey grew out of a conversation with one of my students, Kevin Rossi.

9. Given the manipulation of language that circulates throughout the college sport lexicon, it sometimes becomes difficult to select a term or expression that is not problematized. An example is the "athletic scholarship". While scholar Richard Southall and lawyer Richard Johnson argue that to use the term "athletic scholarship" simply perpetuates a system that has relied on duplicity, the term itself is not logically supportable (scholarship is intended quite literally to support scholarship and academic achievement), the alternative "grant-in-aid" is not without its own problems. The "grant" was intended to suggest a "gift", something that would be offered to the students with no strings attached. Unable to resolve this conundrum of language, the "athletic scholarship" is primarily used here.

10. After a controversial proposal was put forward for debate in 2012 by NCAA Division I schools, the option of awarding four-year athletic scholarships is now available. Most schools, however, have yet to fully adopt them. In April of 2013, Wolverton and Newman reported that only 32 of 56 schools for whom they had data were offering four-year scholarship awards. Only one-tenth of the available scholarship funding was awarded in four year agreements (Wolverton \& Newman, 2013). "[V]ery few elite athletes have benefited," they conclude.

11. The NLRA itself, however, applies only to private institutions, thus college football and men's basketball players at state institutions would confront the issue of having to organize under state labor laws.

12. Johnson (2011), in calling upon the U.S. Congress to regulate the college sport industry, wrote, "Congress doesn't understand the NCAA or how its cabal made up of the conferences, colleges, and universities actually work, which is more an example of modern day facism" (para. 10).

13. College sport historians would note that the seeds of these issues date back to the founding of the NCAA in 1906 and before.

14. According to neurosurgeon Robert Cantu, who serves as the medical director for the National Center for Catastrophic Sports Injury Research, the NCAA failed to ensure that minimal protocols were maintained by athletic trainers when college athletes exhibited signs of concussion. He stated, "Across all aspects of this standard protocol, it is clear the NCAA failed to require (much less explain) appropriate concussion management practices" (Axon, 2013, para. 23).

\section{References}

AAC\&U Board of Directors. (2006). Academic freedom and educational responsibility. Washington, DC: Association of American Colleges and Universities. Retrieved from http://www.aacu.org/about/statements/academic_freedom.cfm

AAUP. (1992). Joint statement on students' rights and freedoms. Washington, DC: American Association of University Professors. Retrieved from http://www.aaup.org/report/ joint-statement-rights-and-freedoms-students

Arrington v. National Collegiate Athletic Association (2011). Case No. 11-cv-06356. Retrieved from http://www.hbsslaw.com/Templates/media/files/case_pdfs/NCAA\%20 Concussions/Arrington\%20NCAA\%20Complaint.pdf

American Council on Education. (2005). Statement on academic rights and responsibilities. Retrieved from http://www.chea.org/pdf/ACE_Statement_on_Academic_Rights_and_ Responsibilities_\%286_23_2005\%29.pdf 
An interview with Morgan Burke and Mike Alden”. (2013, September 27). 351 Division I Programs - One Voice. Cleveland, OH: National Association of Collegiate Directors of Athletics. Retrieved from http://grfx.cstv.com/photos/schools/nacda/sports/nacda/ auto_pdf/2013-14/misc_non_event/D1teleconference.pdf

Associated Press. (2013a, September 21). All Players United: College football players show solidarity with letters 'APU'. Huffington Post. Retrieved from http://www.huffingtonpost.com/2013/09/21/all-players-united-ncaa-college-football-players-apu_n_3968876. html

Associated Press. (2013b, September 23). Georgia Tech coach: Players need team OK for protest. USA Today. Retrieved from http://www.usatoday.com/story/sports/ncaaf/ acc/2013/09/23/paul-johnson-georgia-tech-yellow-jackets-apu-ncaa-protest/2857963/

Axon, R. (2013, July 25). Does NCAA face more concussion liability than the NFL? USA Today. Retrieved from http://www.usatoday.com/story/sports/ncaaf/2013/07/25/ncaaconcussion-lawsuit-adrian-arrington/2588189/

Belzer, J., \& Schwartz, A. (2012, July 25). National letter of indenture: Why college athletes are similar to indentured servants of colonial times. Forbes. Retrieved from http://www. forbes.com/sites/darrenheitner/2012/07/25/national-letter-of-indenture-why-collegeathletes-are-similar-to-indentured-servants-of-colonial-times/

Berkowitz, S. (2013, September 26). NCAA vows to fight O'Bannon suit to the Supreme Court. USA Today. Retrieved from http://www.usatoday.com/story/sports/ ncaab/2013/09/26/ncaa-ed-obannon-ea-sports-lawsuit-supreme-court/2877579/

Branch, T. (2011, September). The shame of college sports. The Atlantic Monthly. http:// www.theatlantic.com/magazine/archive/2011/10/the-shame-of-college-sports/8643/

Byers, W. with Hammer, C. (1995). Unsportsmanlike conduct: Exploiting college athletes. Ann Arbor, MI: University of Michigan Press.

Clifton, G.E. (2013, September 23). College football players engage in protest seeking NCAA reform. Collegiate \& Professional Sports Law Blog. Retrieved from http:// www.collegeandprosportslaw.com/collegiate-sports/college-football-players-protestncaa-for-reforms/

Doughty v. National Collegiate Athletic Association (2013). 3:13-cv-02894-JFA. Retrieved from http://archive.wltx.com/assetpool/documents/131023044228_Stanley\%20 Doughty\%20Complaint.pdf

Eifling, S. (2013, September 25). Iowa State's AD trolled All Players United on Twitter today. Deadspin. Retrieved from http://deadspin.com/iowa-states-ad-trolled-all-playersunited-on-twitter-t-1392479723

Emerson, S. (2013, September 24). Richt, players react to 'All Players United' protest. The Telegraph. Retrieved from http://www.macon.com/2013/09/24/2682787/richt-playersreact-to-all-players.html

Enrie, M. (2010). Totalitarianism. First Principles ISI Web Journal. Retrieved from http:// www.firstprinciplesjournal.com/articles.aspx?article $=974$

Fitzgerald, D. (2009, February 25). Oliver v. NCAA: Court throws out NCAA baseball-lawyer -agent rule. Connecticut Sports Law. Retrieved from http://ctsportslaw.com/2009/02/25/ oliver-v-ncaa-court-throws-out-ncaa-baseball-lawyer-agent-rule/

Forde, P. (2013, September 25). Shame on Northwestern, Georgia Tech for trying to stifle 'All Players United' movement. Yahoo!Sports. Retrieved from http://sports.yahoo. com/news/ncaaf-shame-on-northwestern-georgia-tech-for-trying-to-stifle-apu-movement-230451663.html

Fram, N., \& Frampton, T.W. (2012). A union of amateurs: A legal blueprint to reshape bigtime college athletics. Buffalo Law Review. Retrieved from http://papers.ssrn.com/sol3/ papers.cfm?abstract_id=2001027

Gay, J.W. (2012). Are NCAA student-athlete social media bans unconstitutional? Florida State University Law Review. Florida State University. College of Law, 39, 781-806 
Retrieved from http://www.law.fsu.edu/journals/lawreview/backissues/vol39/documents/gay.pdf.

Green, K., Jaschik, S., \& Lederman, D. (2012, March). The 2012 Inside Higher Education survey of college and university presidents. Washington, DC: Inside Higher Education.

Greenstein, T. (2013, September 24). Fitz: Colter's wristbands a 'teachable moment'. Chicago Tribune. Retrieved from http://articles.chicagotribune.com/2013-09-24/sports/ chi-colter-fitzgerald-20130924_1_teachable-moment-pat-fitzgerald-wristbands

Gruen, S. (2013, September 25). Kain Colter makes statement by promoting players movement. Chicago Sun Times. Retrieved from http://www.suntimes.com/sports/colleges/22795016-419/kain-colter-makes-statement-by-promoting-players-movement. html

Hauer, M. (2012). The constitutionality of public university bans of student-athlete speech through social media. Vermont Law Review 37, 413-436.

Hawkins, B. (2010). The new plantation: Black athletes, college sport, and predominantly white institutions. New York: St. Martin's Press.

Hoffman, J. (2013). Big-time college football and the perils of presidential leadership. Journal of Issues in Intercollegiate Athletics, 10-21. Retrieved from http://csri-jiia.org/ documents/puclications/special_issues/2013/Presidential_Control_02_02.pdf

Hruby, P. (2013a, March 19). The gold-plating of college sports. Sports on Earth. Retrieved from http://www.sportsonearth.com/article/42924176

Hruby, P. (2013b, April 13) Unionize college athletes. Sports on Earth. Retrieved from http:// www.sportsonearth.com/article/44209014/

Hruby, P. (2013c, September 23). United they stand. Sports on Earth. Retrieved from http:// www.sportsonearth.com/article/61573892

Huma, R., \& Staurowsky, E.J. (2010). An examination of the financial shortfall for athletes on full scholarship at NCAA Division I institutions - 2009-2010. Riverside, CA: National College Players Association.

Huma, R., \& Staurowsky, E.J. (2011a). The price of poverty: A comparison of big-time college athlete's fair market value, their current compensation, and the U.S. federal poverty line. Riverside, CA: National College Players Association.

Huma, R., \& Staurowsky, E.J. (2011b). TV money winfall in big time college sports: $\$ 784$ million reasons for reform. Riverside, CA: National College Players Association., Retrieved from http://www.ncpanow.org/releases_advisories?id=0018.

Huma, R., \& Staurowsky, E.J. (2013). The \$6 billion heist: Robbing college athletes under the guise of amateurism. Riverside, CA: National College Players Association.

John Rock v. National Collegiate Athletic Association (2012). Case No. 1:12-cv-1019 JMS-DKL.

Jenkins, M., et al. v. National Collegiate Athletic Association (2014). Retrieved from http://a. espncdn.com/pdf/2014/0317/NCAA_lawsuit.pdf

Johnson, R. (2011, September 19). Solution to NCAA: Legislate free market into college sports. Street \& Smith's SportsBusiness Journal. Retrieved from http://www.sportsbusinessdaily.com/Journal/Issues/2011/09/19/Opinion/Richard-Johnson.aspx

Johnson, R. (2010). Submarining due process: How the NCAA uses its restitution rule to deprive college athletes of their right of access to the courts...until Oliver v. NCAA. Florida Coastal Law Review, 461-638. Retrieved from http://www.fcsl.edu/sites/fcsl. edu/files/Johnson.pdf

Johnson, R. (2013, August 22). The NCAA has never been regulated by Congress, so will Congress finally man-up with proposed new legislation? Sports Law Blog. Retrieved from http://sports-law.blogspot.com/2013/08/the-ncaa-has-never-been-regulated-by. $\mathrm{html} ? \mathrm{~m}=1$

Kaufman, P. (2010). Playing and protesting: Sport as a vehicle for social change. Journal of Sport and Social Issues, 10.1177/0193723509360218. 
Kindred, D. (2011, September 30). Branch's call for college athletics revolution reminiscent of DeVenzio's quest 25 years ago. National Sports Journalism Center Blog. Retrieved from http://sportsjournalism.org/uncategorized/branchs-call-for-college-athleticsrevolution-reminiscent-of-devenzios-quest-25-years-ago/

King, B. J. (1986, January). A radical proposal: Let's pay college athletes. Women's Sport \& Fitness Magazine.

Keller v. Electronic Arts, NCAA, \& Collegiate Licensing Company (2009). Retrieved from http://documents.jdsupra.com/98e583b8-4e5d-4d9e-96e1-3a382e2397f6.pdf

Knight Commission on Intercollegiate Athletics. (2001). A call to action: Reconnecting college sports and higher education. Washington, DC: Knight Commission on Intercollegiate Athletics. Retrieved from http://www.knightcommission.org/presidentialcontrol-a-leadership/commission-reports

Koller, D. (2012). Frozen in time: The state action doctrine's application to amateur sports. St. John's Law Review, 82, 183-236 Retrieved from http://scholarship.law.stjohns.edu/ cgi/viewcontent.cgi?article $=1099 \&$ context=lawreview.

Ley, B. (2013, September 24). Reform movement in college sports? ESPN.com. Retrieved from http://espn.go.com/new-york/college-football/story/_/id/9259610/columbia-lionsrespond-report-racist-tweets-football-players

Lockhart, M. (2010). Oliver v. NCAA: Throwing a contractual curveball at the NCAA's veil of amateurism. University of Dayton Law Review 35 (2), 175-198.

McCann, M. (2013a, June 19). NCAA v. O’Bannon class certification hearing primer. Sports Illustrated. Retrieved from http://sportsillustrated.cnn.com/college-football/ news/20130619/ncaa-ed-obannon-hearing-primer/

McCann, M. (2013b, July 19). Why aren't current basketball players added to O'Bannon suit? Sports Illustrated. Retrieved from http://sportsillustrated.cnn.com/college-basketball/ news/20130719/no-current-basketball-players-in-obannon-suit/

McCormick, R., \& McCormick, A. (2006). The myth of the student-athlete: The college athlete as employee. Washington Law Review. Retrieved from http://digitalcommons. law.msu.edu/facpubs/280/

McKenna, D. (2010, December 10). Athletes don't go to Howard University for the food! Washington City Paper. Retrieved from http://www.washingtoncitypaper.com/blogs/ citydesk/2010/12/10/athletes-dont-go-to-howard-university-for-the-food/

Meggysey, D. (1970). Out of their league. Berkley, CA: Rampart Books. Note: a second edition of the book was published in 2005 by Bison Books.

Miller, V. (2008, March 19). Boulder high students rally for fired coach. Daily Camera. Retrieved from http://www.dailycamera.com/ci_13138961

Munson, L. (2014, March 27). NLRB decision very well reasoned. ESPN.com. Retrieved from http://espn.go.com/espn/otl/story/_/id/10678393/nlrb-director-decision-followsroad-map-laid-northwestern-quarterback-kain-colter-legal-team

NCAA Academic and Member Affairs Staff. (2013). Division I Manual 2013-2014. Indianapolis, IN: National Collegiate Athletic Association. Retrieved from http:// www.ncaa.org.

National College Players Association. (2013). All Players United. Retrieved from http://afl. salsalabs.com/o/5889/c/754/p/dia/action3/common/public/?action_KEY=7031

Northwestern University. (2013). Policy statement on student rights and responsibilities. Retrieved from http://www.northwestern.edu/student-onduct/conduct/rights/students.html

O'Bannon v. National Collegiate Athletic Association, and Collegiate Licensing Company (2009). CV no. 09-3329. Retrieved from http://www.hausfeldllp.com/content_documents/9/FileStampedNCAAComplaint072109.pdf

Ohr, P.S. (2014, March 26). Northwestern University and the College Athletes' Players Association. Case no. 13-RC-121359. Chicago, IL: National Labor Relations Board. Retrieved from http://www.nlrb.gov/news-outreach/news-story/nlrb-director-region13-issues-decision-northwestern-university-athletes 
Oriard, M. (2003). King football: Sport and spectacle in the golden age of radio and newsreels, movies and magazines, the weekly and the daily press. Chapel Hill, NC: University of North Carolina Press.

Oriard, M. (2009). College football's season of discontent: How today's game was shaped by the racial strife of 1969. Slate Magazine. Retrieved from http://www.slate.com/articles/ sports/sports_nut/2009/09/college_footballs_season_of_discontent.html

Penrose, M. (2013). Outspoken: Social media and the modern college athlete. The John Marshall Review of Intellectual Property 12 (3), 509-550. Retrieved from http://repository. jmls.edu/cgi/viewcontent.cgi?article=1306\&context=ripl

Potter, J. (2007). The NCAA as state actor. University of Pennsylvania Law Review, 155, 1269-1304 Retrieved from https://www.law.upenn.edu/journals/lawreview/articles/ volume155/issue5/Potter155U.Pa.L.Rev.1269\%282007\%29.pdf.

Prewitt, A. (2013, September 25). Maryland coach Randy Edsall talks All Players United campaign, national attention. Washington Post. Retrieved from http://www.washingtonpost. com/blogs/terrapins-insider/wp/2013/09/25/maryland-coach-randy-edsall-talks-allplayers-united-campaign-national-attention/

Remy, D. (2014, March 26). NCAA disagrees with union decision. Press release. Retrieved from http://www.ncaa.org/about/resources/media-center/press-releases/ncaa-disagreesunion-decision

Rhoden, W. (2006, October 22). Syracuse honors nine players who took a stand. New York Times. Retrieved from http://www.nytimes.com/2006/10/22/sports/ ncaafootball/22rhoden.html?_r=0

Rosenberg, A. (2013, September 10). Billie Jean King on paying college athletes, leaning in, and the future of feminism. Think Progress. Retrieved from http://thinkprogress. org/alyssa/2013/09/10/2601351/american-masters-billie-jean-king/

Sack, A.L. (1982). Cui bono? Contradictions in college sports and athletes rights. In J. Frey (Ed.), The governance of intercollegiate athletics (pp. 80-90). West Point, NY: Leisure Press.

Sack, A.L. (2008). Counterfeit amateurs: An athlete's journey through the sixties to the age of academic capitalism. University Park, PA: The Pennsylvania State University Press.

Sack, A.L., \& Staurowsky, E.J. (1998). College athletes for hire: The evolution and legacy of the NCAA amateur myth. Westport, CT: Praeger Press.

Schott, T. (2013, September 25). 351 Division I programs - One voice. Press release. Retrieved from http://www.nacda.com/sports/nacda/spec-rel/092513aaa.html

Schroeder, G. (2013, October 22). Grambling players provide shocking details, reason they ended boycott. USA Today. Retrieved from http://www.usatoday.com/story/sports/ncaaf/ swac/2013/10/21/grambling-players-provide-shocking-details-former-coach-swayedthem-back-out-of-protest/3144353/

Shear, B. (2013, April 23). Utah bans student-athlete social media monitoring firms. Shearsocialmedia.com. Retrieved from http://www.shearsocialmedia.com/2013/04/ utah-bans-student-athlete-social-media.html

Southall, R.M. (2012). College sport reform: Déjà vu all over again and again. In G. Sailes (Ed.), Sports in higher education: Issues and controversies. San Diego: Cognella Academic Publishing.

Southall, R.M., \& Staurowsky, E.J. (2013). Cheering on the collegiate model: Creating, disseminating, and embedding the NCAA's redefinition of amateurism. Journal of Sport and Social Issues (online). Retrieved from http://intl-jss.sagepub.com/content/ early/2013/08/21/0193723513498606.abstract

Southall, R., \& Weiler, J. (2013, January). Division I college athletic departments: Utopian or exploitative company towns. Paper presented at the NCAA Scholarly Colloquium, Grapevine, TX.

Staff. (1986). Scouting: Showdown, yes, but no sitdown. New York Times. Retrieved from http://www.nytimes.com/1986/11/19/sports/scouting-showdown-yes-but-no-sitdown. html 
Staff. (2013, November 20). Cardenas introduces law to protect collegiate student-athlete academic progress. Press release. Retrieved from http://cardenas.house.gov/media-center/ press-releases/c-rdenas-introduces-law-to-protect-collegiate-student-athlete-academic

Staurowsky, E.J. (2004). Piercing the veil of amateurism: Commercialisation, corruption, and college sports. In T. Slack (Ed.), The commercialisation of sport (pp. 143-163). London, England: Frank Cass Publishers.

Staurowsky, E.J. (2011, December 1). Urban and Me: We're almost exactly the same except for that \$26 million contract. College Sports Business News. Retrieved http://collegesportsbusinessnews.com/issue/october-2012/article/urban-and-me

Staurowsky, E.J., \& Sack, A.L. (2005). Reconsidering the use of the term "student-athlete" by academic researchers. Journal of Sport Management, 19(2), 103-117.

Student rights and responsibilities". (2013). Office of Student Conduct. Athens, GA: University of Georgia. Retrieved from http://conduct.uga.edu/students/rights.html

Underwood, J. (1969, August 29). The desperate coach. Sports Illustrated

Uthman, D. (2013, September 21). College teams wear 'APU' in organized protest of NCAA. USA Today. Retrieved from http://www.usatoday.com/story/sports/ncaaf/2013/09/21/ college-football-apu-all-players-united-ncpa-ramogi-huma/2847203/

Uthman, D. (2013, October 17). North Carolina players to display 'APU' tonight v. Miami. USA Today. Retrieved from http://www.usatoday.com/story/sports/ncaaf/acc/2013/10/17 /thursday-night-college-football-north-carolina-tar-heels-miami-apu-all-playersunited/3004963/

Vint, P. (2014, March 27). Explaining what the Northwestern college football union decision means. SBnation.com. Retrieved from http://www.sbnation.com/college- football/2014/3/27/5551014/college-football-players-union-northwestern-nlrb

Volk, P. (2013, September 23). College football players protest the NCAA during games, and the reaction is mostly positive. SB Nation. Retrieved from http://www.sbnation. com/college-football/2013/9/23/4761480/apu-college-football-player-protest

Walsh, D. (2011). All a twitter: Social networking, college athletes, and the First Amendment. The William and Mary Bill of Rights Journal, 20(2), 619-650.

Weiner, R. (2012, August 13). Ohio athletes sue NCAA in antitrust over scholarship allocations. Akron Legal News. Retrieved from http://www.akronlegalnews.com/ edito$\mathrm{rial} / 4465$

Wiggins, D.K. (1988). "The future of college athletics is at stake": Black athletes and racial turmoil in three predominantly white university campuses, 1968-1972. Journal of Sport History, 15(3), 304-333.

Wolverton, B. (2013, November 21). Bill in Congress aims to protect athletes at wealthiest colleges. The Chronicle of Higher Education. Retrieved from http://chronicle.com/ blogs/ticker/bill-in-congress-aims-to-protect-athletes-at-wealthiest-colleges/69513

Wolverton, B., \& Newman, J. (2013, April 19). Few athletes benefit from move to multiyear Scholarship. The Chronicle of Higher Education. Retrieved from http://chronicle.com/ article/Few-Athletes-Benefit-From-Move/138643/

Woods, D. (2013, September 24). Indiana football players were oblivious to 'All Players United' effort. Indianapolis Star. Retrieved from http://www.indystar.com/ article/20130924/SPORTS0601/309240066/Indiana-football-players-were-obliviousAll-Players-United-effort 